\title{
ABANDONED VILLAGES AND RELATED GEOGRAPHIC AND LANDSCAPE CONTEXT: GUIDELINES TO NATURAL AND CULTURAL HERITAGE CONSERVATION AND MULTIFUNCTIONAL VALORIZATION
}

\author{
Marisa Filipe $^{1} \&$ José Manuel de Mascarenhas ${ }^{2}$
}

Received 30 March 2010; Accepted 23 May 2011

\begin{abstract}
Villages abandoned in the last decades as a result of the inland rural areas migration are a serious and common problem in many European countries requiring a strict attention from the politicians and the community in general. The authors looked into this problem in the Portuguese context, with special emphasis on the deserted village of Broas, close to Sintra, in the province of Estremadura, Western Portugal. Firstly, the general causes of human abandonment of rural areas were analysed especially in what concerns the evolution of national and E.C. agrarian economy and other social issues, related particularly with lack of quality of life and well being. The subsequent problems of heritage conservation required also a certain attention from the authors. In fact, many of the abandoned villages have valuable vernacular heritage elements and are involved by cultural landscapes, sometimes also of heritage value. As these inland areas have in general escaped to farming intensive pressure, an important natural heritage frequently exists. Different approaches to heritage valorization, based on different Portuguese experiences and other concepts, were also examined by the authors. These processes can go from the simple interpretation centre to the eco museum development or the building recovery for tourism purposes. Nevertheless, the main measures for the reinvention of the rural must be related to the establishment of economic opportunities for new inhabitants that should be based on multifunctional agro re-conversion activity adapted to small parcels and extensive systems, associated or not with small craft industries.
\end{abstract}

Keywords: land abandonment; Deserted villages; Heritage valuation; Cultural landscape; multifunctional agro re-conversion activity transition

Resumo: As aldeias abandonadas, nas últimas décadas, em consequência da migração interna das áreas rurais, são um problema sério e comum em muitos países europeus que exigem uma atenção constante dos políticos e da comunidade no general. Os autores abordaram este problema no contexto português, com especial

\footnotetext{
${ }^{1}$ Cultural Heritage Degree; filipemarisa@gmail.com

2 Ph.D. in Land Planning, Évora Univ. Professor, Researcher in CIDEHUS - Évora Univ. Centre; mascarenhas_jm@sapo.pt
} 
enfoque na aldeia abandonada das Broas, situada perto de Sinta, na província da Estremadura, Portugal ocidental. Inicialmente, analisaram-se as principais causas do abandono das áreas rural, especialmente no que diz respeito às políticas nacionais e europeias de economia agrária e outras questões sociais, relacionadas com a perda de qualidade de vida e bem-estar. Os problemas decorrentes deste abandono reflectem-se também no património, tendo os autores abordado este aspecto específico. De facto, a maiorias destas aldeias dispõem de numerosos elementos de interesse vernacular, envolvidos em paisagens culturais, sendo também estas, muitas vezes, de grande valor patrimonial. Como, em geral estas aldeias não foram alvo de grandes pressões agrícolas, a sua paisagem natural manteve-se intacta. Os autores examinaram diferentes formas de tratar e valorizar o património vernacular, tendo por base diferentes experiências portuguesas e também outros conceitos. Estes processos de valorização vão desde a criação de simples centros de interpretação e instalação de ecomuseus, até à recuperação destas aldeias para fins turísticos. Seja como for, as principais medidas para a reinvenção das áreas rurais deve estar sempre relacionada com a criação de novas oportunidades económicas para novos habitantes, baseadas numa agroreconversão multifuncional adaptada a pequenas parcelas e usos agrícolas intensivos, associados ou não a pequenas industrias.

Palavras-chave: abandono das terras, aldeias desertas, heritage avaliação, paisagem cultural, transição atividade multifuncional agro reconversão

\section{Introduction}

The first aim of the research concerns the analysis of the abandonment of villages, particularly in which concerns its causes and social and environmental impacts. As a study case we have chosen the village of Broas, in the surroundings of Lisbon; the guidelines to the natural and cultural heritage conservation and multifunctional valorization were also analysed.

Concerning the organization of the paper, in first chapter the authors present the problem of the agricultural abandonment as well as the villages' desertification. In the following chapters the Broas study-case was analysed. After a geographical and historical characterisation and the village description, several models of the site valorization were presented. Among them, the cultural park based in an eco-cultural tourism context seems the most interesting solution. Finally, the most adequate administrative structure is exposed and an example of operational guidelines is proposed.

The methodology adopted was mainly a geographical approach based in terrain surveys, aerial photo-interpretation and empirical data. We have tried to understand the Broas real situation using a scientific horizontal perspective. In fact, through this approach, the proposed valorization solutions and guidelines are well adapted to the specific case-study context.

\section{The agricultural abandonment and the desertification of villages}

\subsection{The agricultural abandonment}

The various causes of the agricultural abandonment can be summarized as follows:

\section{- Economical causes:}

Marginalization of the use of the soil as a result of a little income-producing agriculture due to the small dimension of properties, frequently associated with the weak agrological quality and low productivity of soils, to folded and declivous lands and to the deficient accessibilities. Thus, small-scale and extensive farming systems cannot be competitive in the global agricultural market and exploitations become financially impracticable.

Even though one can see a resistance to the agricultural abandonment in some Portuguese agricultural zones, mainly due to a strong emotional and cultural link to the land rather than an economic interest in the agricultural activity (off-farm jobs support frequently 
the maintenance of the landholding) (Sedimayr, 2008), the majority of the farmers subsist mainly thanks to the subsidies of the European Community, as it becomes cheaper to import foods from foreign countries. These subsidies allow many of the most picturesque European cultural landscapes to subsist nowadays.

- Social causes:

Ageing population resulting mostly from low birth-rates.

Low academic qualifications of farmers.

Distance of many rural areas from the main decision poles.

Generally, serious gaps, in terms of equipment and supporting infrastructures:

- Deficient accessibility;

- Inexistent or difficult access to health, education and leisure services;

- Lack of basic sanitation, water and light.

- Lack of innovation, investments and entrepreneurship within the agricultural sector.

- Psychological causes:

The great attraction to urban areas is no doubt one of the main factors which may explain the agricultural abandonment.

It is based on various psychological reasons, such as: the search of a better quality of life, improvement of social level face to the local population, the urban way of life, and several other aspects with more or less significance.

As a result of the disqualification that the agricultural areas have been suffering in the last few decades, mostly by media, the agricultural population feels bad and inferior to the "other" (the urban one).

Frequently it is children who start abandoning the village, then pressure parents to do the same.

The bigger development of neighboring communities, can lead members of a determined local community to build houses in these localities. The abandonment of the first house might not be immediate, but it turns out permanent as the years go by.

- Other causes:

Politics priorities of European CAP: scanty promotion of small-scale farming systems and farming for food self-sufficiency.

Municipal political priorities: lack of political will from the autarchies to face the situation, frequently associated to an economical lack of capacity to implement mechanisms of support to the agricultural development.

Forestry strategies regarding land occupation.

Subdivision of the property resulting from inheritance processes, many of these becoming hardly viable exploitations, from the economical point of view. On the other hand, the consequent multiplication of landowners, in many cases can make difficult the possibility of realizing transactions.

The exodus of a village is seldom caused by expropriation due to public works of great dimension and national interest.

The reasons pointed out above allow us to understand the enormous agricultural exodus that took place in Portugal, since the 50's, to urban areas and/or foreign countries.

\subsection{Villages desertification: first causes}

The abandoned villages are an extreme case of a much more general phenomenon: the abandonment of vast agricultural areas, mainly in the most mountainous and isolated zones, the general causes of which have been summarized in the previous chapter. 
More specific and local causes can be considered, such as environmental problems related to natural resources (the lack of water, for instance) or specific calamities, as epidemics, earthquakes and volcanic eruptions, landslides, fires, catastrophic floods, etc.

Other causes are socio-economical events related to the historical processes, as alterations of commercial routes, destruction following wars, shares of expropriation following projects of national interest, other decisions concerning politics. Also some laboring villages mostly linked to the mining industry are known to end up depopulated due to bankruptcy of their companies.

In Portugal, the number of villages that disappeared is also substantial as we can see by maps dating from the $17^{\text {th }}$ and $18^{\text {th }}$ centuries, many of them along main roads.

\section{Relevant socio-environmental impacts}

\subsection{Natural heritage impacts}

The traditional agro-pastoral systems frequently present a high biological diversity since those areas were grazed over long timescales (González Bernáldez, 1991). For that reason around half of the European Natura 2000 Network sites designated under the Habitats and Species Directive (92/43/EEC) are farmed environments (Bennet, 1997, cit. by MacDonald et al., 2000).

Traditional farming systems present public benefits through their maintenance of landscapes, provisions of habitats and embodiment of cultural heritage (MacDonald et al., 2000).

The environmental impacts related with the abandonment of these systems can be classified in three main categories: biodiversity (including habitats), risk of wild fires, and natural hazards such as risk of soil erosion and landslides.

Biodiversity refers to the biological variability either at the level of the species richness, ecosystem diversity and/or complexity, or genetic variation (MacDonald et al., 2000).

The abandonment of traditional agro-systems induces the development of shrub encroachment and coarse grasses decreasing biological diversity and increasing the potential for fire (González Bernáldez, 1991; MacDonald et. al., 2000). Concerning the risk of natural hazard, it increases in the short-term, but it lessens considerably over longer periods. The risk of fire may increase initially accompanying the coarse and dry grasses development but as tree cover improves and influences ground vegetation, risk of fire may decrease, although this process may involve time periods of 50 years or more (idem). But a serious problem is the interaction fire-erosion-desertification. "Not only does fire pose a threat to natural and agricultural flora and fauna but interacts with erosion processes in dry climatic zones. When fire interrupts the succession process then a protective scrub cover is not formed and sheet wash erosion may result in loss of productivity top soil "(Garcia-Ruiz et al., 1991, cit. by MacDonald et al., 2000). In Mediterranean arid zones, this process can culminate in an irreversible desertification situation (MacDonald et. al., 2000).

Other kind of negative environmental impacts can be yet found as loss of pastoral value, threatened vulnerable and rare species and remaining agriculture disturbances. Concerning this last aspect, if a parcel is abandoned this may produce the invasion of pests and weeds in adjacent parcels or shrub encroachments and shading from forest regeneration. Nevertheless these adjacent abandoned areas can present also positive effects as refuges for species which contribute to pest control.

In terms of Human Ecology, negative impacts can also be found. The degradation of the traditional agro-systems is also reflected in environmental friendly lifestyles (lowconsumption lifestyles) disappearance.

On the other hand, those systems may be considered as a "source of inspiration for new forms of landscape design and management practices. Research into these vanishing ecosystems is important in order to combine their favourable environmental characteristics with technical and social progress." (González Bernáldez, 1991). The disappearance of such systems as well of the ecological knowledge of traditional farmers must be assumed as an important negative environmental impact. 


\subsection{Cultural heritage impacts and landscape impacts}

How great is the loss when villages are abandoned in terms of built heritage?

Obviously this heritage allows evoking life in those habitats and work of our ancestors, so these places must be seen as sites of memory (Châtelain, 1998). As there is often few material evidences of the past communitarian societies, these remains are commonly called minor heritage, or better, vernacular heritage, which is not a pejorative meaning and, according to its etymological root, is more suitable to identify cultures through consistencies (Bronner, 2006). Essentially they are elements representing the daily life activities (Labille, 2007).

As the force of tradition in the social construction is unquestionable and impose similarities, the importance of the perception of the cultural precedent through which forms are generated (Bronner, 2006) gives us an idea of the impact resulting from this heritage loss. This heritage also represents habits and customs of the daily life, religious and/or festive events and collective memories, so its loss means an ethnographic impoverishment.

Another aspect of the impact caused by the agricultural abandonment is related with the landscape, in particular with the degradation of the traditional landscapes. As a result of the agro-abandonment, landscapes patiently constructed from generation to generation, frequently characterized by agricultural parcels divided by walls, hedges or in terraces, can quickly be covered by brushwood and its structures turned into ruins.

This affectation can also assume still highly troublesome aspects in case that the cultural landscape in question is retainer of a raised patrimonial value, resulting from the existence of elements of old landscape structures in it (of cadastre nets, of irrigated land, etc.) characteristic of different times in the past.

Once the landscape diversity is also affected, the area will be also weakened in terms of landscape ecological values, with special relevance for the heterogeneity and the connectivity of landscape, resulting mostly from the degradation in the net of the hedges and other ecological corridors, which will be reflected in the biological impoverishment of the area.

The population decline worsened by rural exodus and economic viability problems puts at risk the future of these heritage landscapes. Furthermore there has been an increase of the pressure to reduce the financing subsidies for the landscapes conservation (Theil, 2009).

\subsection{The social trauma}

Being the landscapes factors of the territorial identities and therefore guards of the sense of place, the topophilia and the terraphilia (Roca, 2009), its degradation corresponds to an evident negative social impact in what concerns self-esteem, self-recognition, and the hope in a better future and several sources of comfort (Roca \& Oliveira, 2005). This problem is very worrying, mostly in Portugal, affecting the territorial identity more often and in a bigger scale than the efforts to the protection and valorization of the landscape. The perspectives of sustainable development are also being affected by this problem (idem).

This trauma is very serious, as most of the people dislocated to urban areas convinced themselves that their life in the city or industry had no future, ending by dragging themselves or dying, in a process that normally takes tens of years (Martinez, 1993) and this is accompanied by the deterioration of the equipment from their old village. If the loss of heritage is already very serious, the loss of labor is even worse (idem).

\section{The deserted village of Broas as a case study}

\subsection{Geographical and historical context}

\subsubsection{Physical geography and landscape}

The village of Broas is situated in the municipality of Mafra, about $5.8 \mathrm{~km}$ south of this village and $8.3 \mathrm{~km}$ from the Atlantic coast. Nowadays it belongs to the district of Cheleiros from which it stands at a distance of $1.3 \mathrm{~km}$. Otherwise this village belongs to the Lisbon Metropolitan Area, about $25 \mathrm{~km}$ far from this city (Figure 1). 
The involving region of Broas is characterized by a wavy relief, cut by the deep valley of Cheleiros stream and by a climate with mild temperatures (annual average temperature: $14.6^{\circ} \mathrm{C}$ ) due to maritime influence, an annual average precipitation of $860 \mathrm{~mm}$ (Mendes et al., 1991) and frequent fogs.

In bioclimatic terms, according to the classification of S. Rivas-Martinez (2005), this region corresponds to the mediterranean pluvioseasonal-oceanic type and biogeographically, according to this author, to the Olissiponense district, on the basis of his classification. This district corresponds to the area commonly called the saloia region, of great geologic diversity, where limy, sandstones and marls alternate with eruptive rocks of the volcanic Lisbon - Mafra complex.

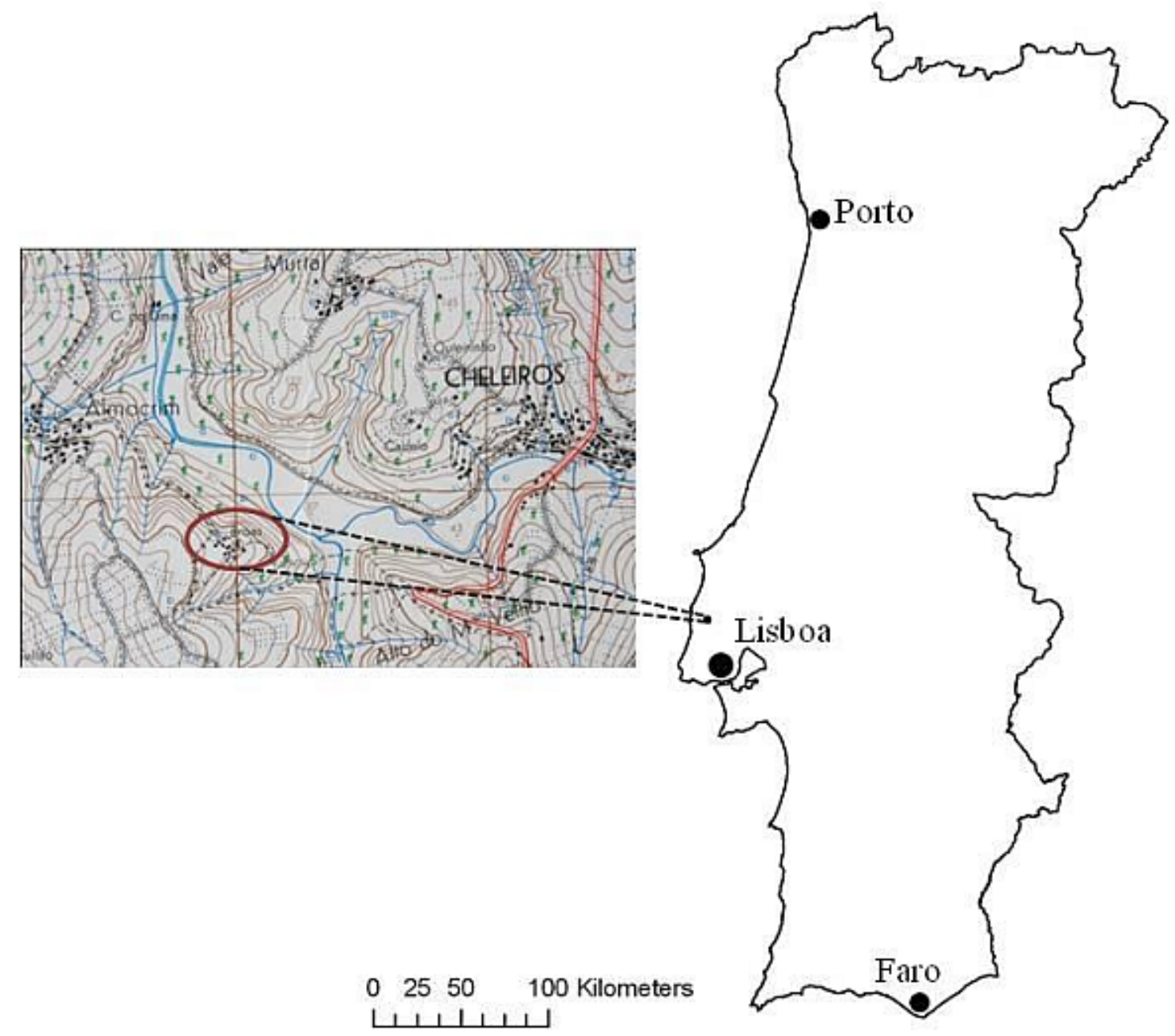

Fig 1. Location of the village of Broas (author: J. M. Mascarenhas; drawing: C. Carriço, 2011).

Inside that region, the village of Broas is inserted in a dominant point of the valley of Cheleiros (Figure 2), on calcareous rocks and marls of the Cretaceous (Almeida, 1991).

The involving landscape has a singular nature, defined by a mosaic of cultures, of pastures and brush woods, delimited by walls of dry stones. Among them, quickset hedges, mostly of Spinosa Prunus subsp. insititioides (Costa et al., 1998) can often be seen. By comparing air photographs of 1946 and 2007, some old agricultural parcels are now found in a state of abandonment (Figures 3 and 4). This is a trend which can also be observed at a national scale, but in this region the phenomenon is quick due to the increasing pressure of construction (mostly houses, expansion of the urban centres and other types of buildings). Despite of the degrading tendencies, this landscape unit still keeps a certain identity and a reasonable coherence of uses (Abreu et al., 2004). 


\subsubsection{Relevant historical incidents}

\subsubsection{The involving area of Broas until the end of the Middle Ages}

The first information known about the village of Broas dates from 1527 but its area of implantation is so rich in historical and archaeological signs that it is essential to study it. The archaeological clues reveal an attractive area for human communities since pre-historic times. The Cheleiros stream and its involving area functioned as a border and population centre in the Mafra-Sintra region (Sousa, 1998). There are signs that the area was occupied during the Palaeolithic period, a set of small settlements appear on the left bank of the stream (the bank where Broas is situated). The sandy soils were fertile for agriculture; however in this period agricultural tools did not exist to allow a good exploration, so other subsistence activities were, probably, developed as small pastures and fishing in the Cheleiros stream. A great amount of archaeological findings allow us to support the idea that all the area of Faião (Sintra), a few kilometres from Broas, had h great importance during the Roman period, the High Middle Age and even during the Muslim occupation. The findings lead us to believe that Faião was a vicus, probably the Roman Chretina (or Chrestina), referred to by Claudio Ptolomeu in the $2^{\text {nd }}$ Century of our Era (Rodil \& Carvalho, 1995). Thus, Faião - Chretina would be one of the main habitats of the Estremadura, after the city of Olisipo, the actual Lisbon. In the $11^{\text {th }}$ and $12^{\text {th }}$ centuries, Islamic sources describe the region of Sintra as an area rich in natural resources, that allowed the development of grazing and, due to its proximity to the Atlantic Ocean, the use of marine resources (Coelho, 2000). This affirmation is supported by the predominant Arabian toponymy as well as by the 1154 Charter (foral) of Sintra, which defined the area to cultivate and to plant from the Sintra Castle to the Cheleiros stream. Furthermore it is certain that this area was a centre of attraction and of great population.

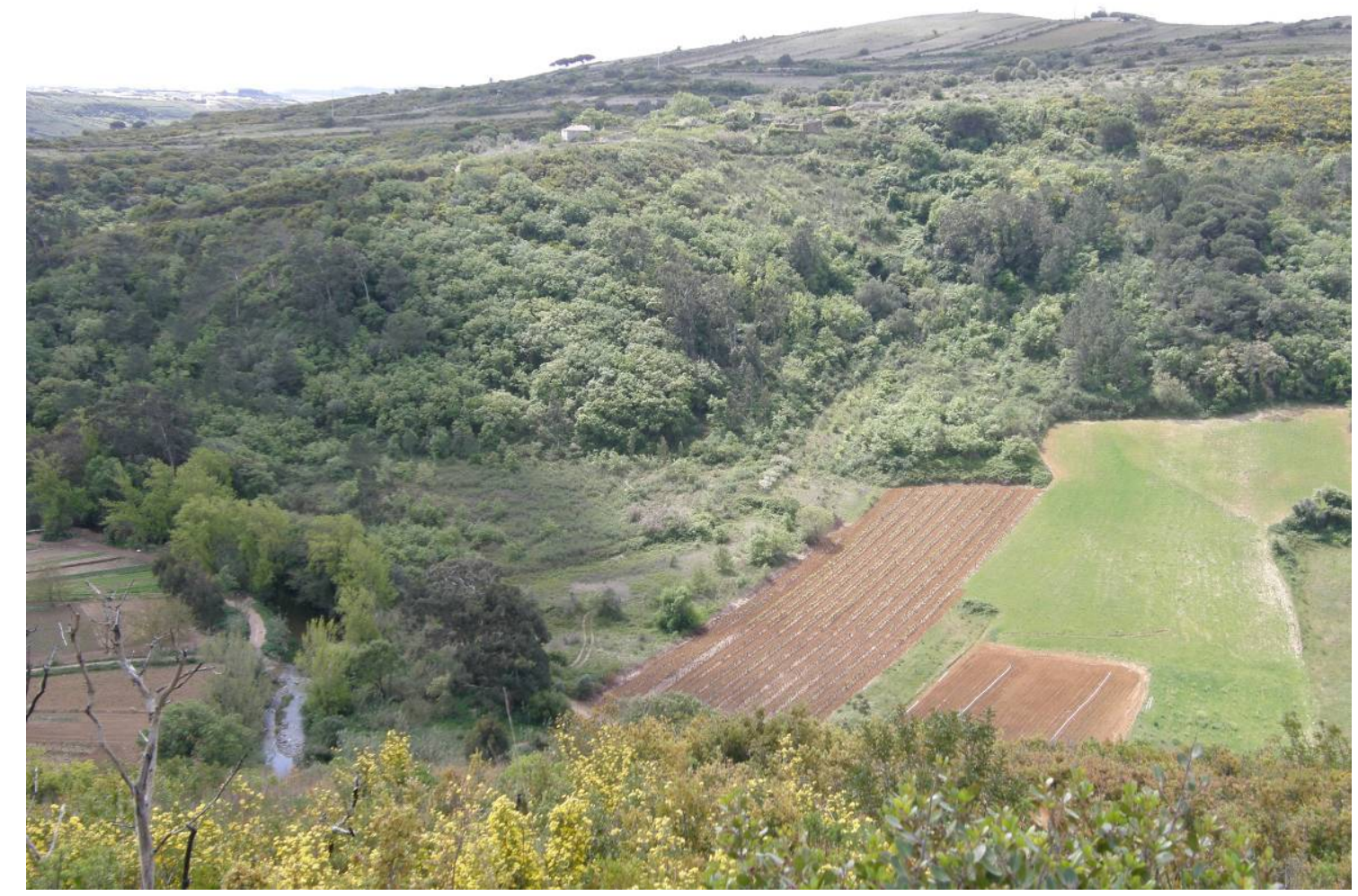

Fig 2. View of the Cheleiros stream valley. The village of Broas can be seen on the border of the background plateau (author: J. M. Mascarenhas, 2009).

\subsubsection{Other historic elements of Broas}

As mentioned above, the first information known about Broas dates from 1527 and appears in the census (numeramentos) concerning the region of Estremadura. This survey of the population was ordered by King João the Third and covered all the kingdom of Portugal. 
The village of Broas was then called Aldea de Boroas, registers three "neighbours", i.e. inhabitants (housing occupation close to the average), and is at the limit of the village of Chilleiros. It is not possible to understand the village of Broas without studying the village of Cheleiros, as these two populations are intrinsically related. Cheleiros received its 1 st Charter (Foral) in 1195, and a second one granted by King Manuel the First, in 1516, as it was a village of some importance since early times. In 1636 King Filipe the Third orders the census of the people in the whole kingdom of Portugal. Broas appears with 6 neighbours (Matta, 1981) which means that its resident population increased.

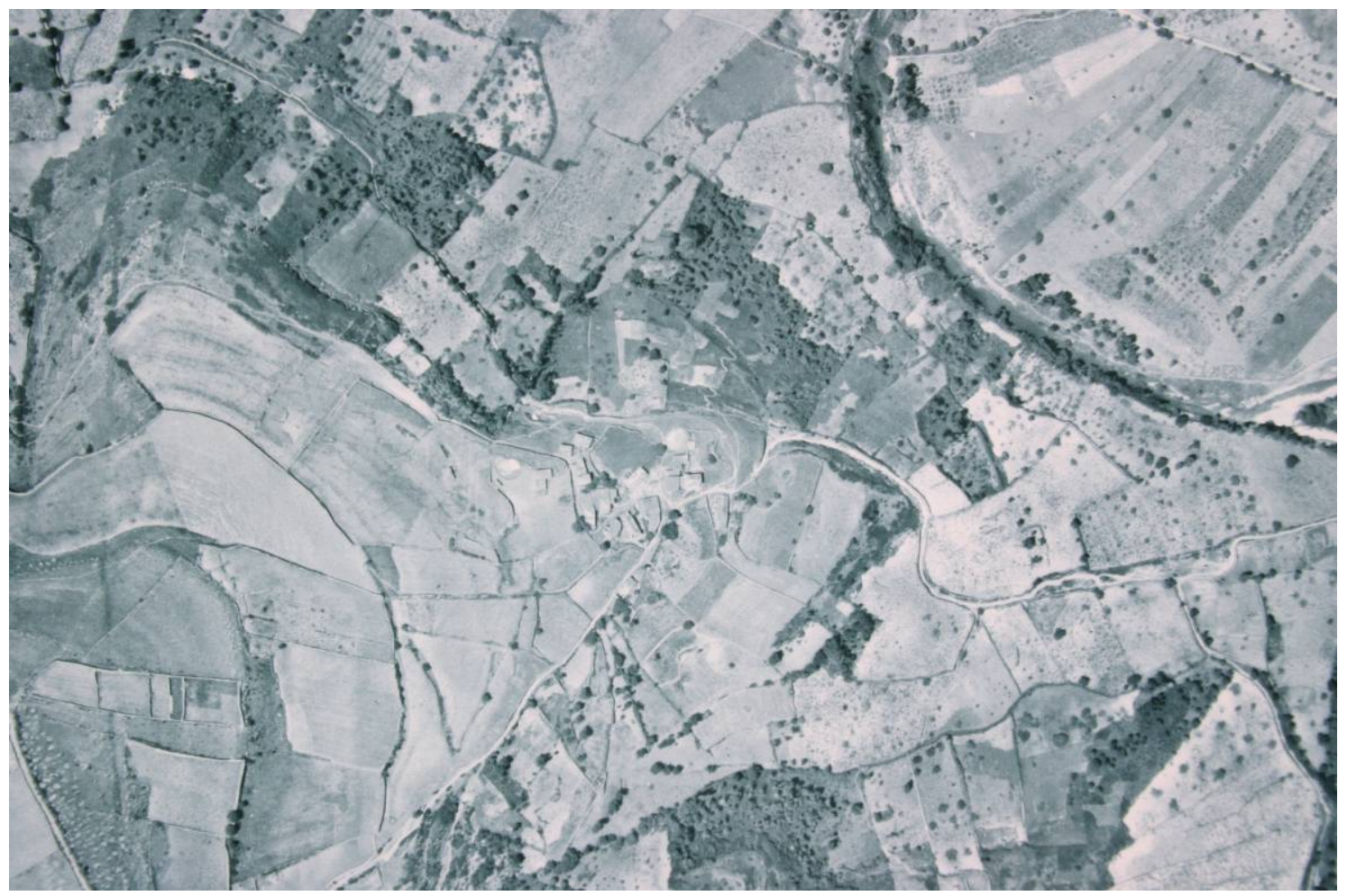

Fig 3. Vertical aerial photograph showing the village of Broas and the involving landscape (Mafra mission, 1946), (C Instituto Geográfico Português).

The village is referred to again in 1758, in Memorias Paroquias (Parish Memories), an exact survey of all the lands and their belongings, carried out under the control of King Jose the First, to know the many dammages suffered by the country as a result of the 1755 earthquake. Curiously, in these Memories Broas appears within the boundaries of Sintra (Borges, 1758). From 1758 there is a time gap and it is only in 1876 that further information about the village is known (Batista, 1876). This author mentions Broas as an integrant part of the Recamador parish, in Cheleiros, with only 4 neighbours, which leads us to assume that Broas population was declining. In 1834 the administrative division between the municipalities of Mafra and Sintra was defined. In 1836 the municipality of Cheleiros was extinct by a Decree Law of $29^{\text {th }}$ November and integrated as a parish in the municipality of Sintra. But this integration did not coincide with the administrative division made in 1834 , and it is probably the main reason why the parish of Cheleiros was transferred to the municipality of Mafra by the Decree of $24^{\text {th }}$ October 1855 (Lopes, 2006). In 1936 the village of Broas is again mentioned as integrant part of the parish of Cheleiros, which belonged to the town of Mafra (Costa, 1936). Presently, the limit of the municipalities crosses Broas, one house standing inside the administrative area of Sintra, probably built by the end of the twenties (Baleia, 2009), and the remaining ones belonging to the municipality of Mafra (Figure 4). The history of this village and its population ends in the year of 1977 , when the last inhabitant, Ti' Jaquina, abandoned the village thirty years ago and never came back. 


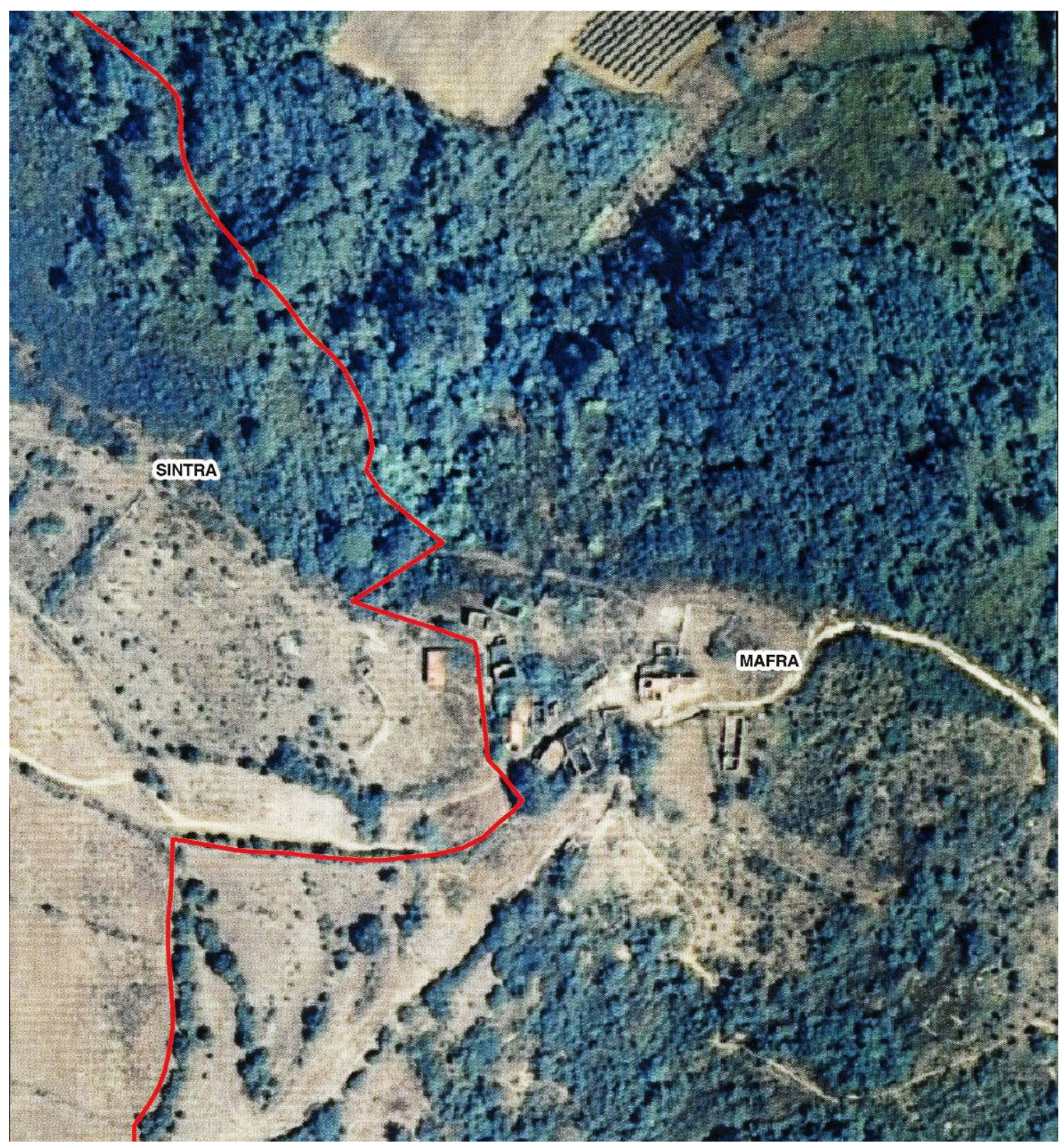

Fig 4. Vertical aerial photograph showing the village of Broas and the involving landscape (Mafra mission, 2009). The red line shows the frontier between Sintra and Mafra municipalities (C) Câmara Municipal de Mafra).

\subsubsection{Human geography}

\subsubsection{The Saloio as a human type}

Who is the Saloio? Where does he come from? These apparently simple questions are the centre of great controversy and discussions. The theatre and literature of the $16^{\text {th }}$ century had already identified and made fun of this genre, but it is in the $19^{\text {th }}$ century that the saloio is considered as a social type (Costa, 1996). The saloio is then understood as another type of people from the outskirts of the capital. While the inhabitant of Lisbon is educated, correct, and with a lighter skin tone, the saloio is the opposite: harsh, darker skin tone, materialistic, moneygrabber, sneaky, superstitious, and a person always trying to cheat the other without success, which gives him a so called esperteza saloia (pragmatic cleverness) (Pimentel, 1908). Most of the researchers attribute Arabian phonetics to the saloio term, which may indicate an Arab or Moorish origin, with a lot of different proveniences and meanings: of prayer (çala), sect (çaala), greeting (salé)... In 1917 David Lopes presents a thesis that congregates some consensus between the scholars: the saloio term will have evolved to leave the Arab term Çahroi that would mean, in its origins, inhabitant of the field (Costa, 1996). Without any doubt or discussion, the saloio is recognized as the one who works on the land, he possesses a true attachment to agriculture (Fontes, 1943) and was the main supplier of services to the city of Lisbon. Therefore 
he not only supplied food, but also a variety of man power to the Lisbon population, laundrywomen for example. Curiously, the saloio does not think of himself as an autonomous entity until 1980, when the population of this area started to define themselves as saloias and they adopt this definition as a mark and gave it a commercial meaning.

\subsubsection{The traditional agriculture}

In the middle of the $18^{\text {th }}$ century, the main agricultural productions in the district of $N^{a} . S r^{a} d a$ Assunção de Cheleiros were wheat, barley, some maize, wine and a small quantity of olive oil (Abreu, 1758). In the Cheleiros stream barbells, mullets, grey mullets and tortoises could be freely caught (Cardoso,1751). The agriculture around Broas was well adapted to the biogeographical conditions of the area, especially to the limy Cretaceous soil difficult to farm, demanding constant tilling, but fertile when adequately prepared (Boléo, 1973).

More recently, in the middle of last century, the cereals cultivated in this region were wheat, barley, oats and in a much more limited range maize and other horticultural products (Baleia, 2009). Wheat was cultivated in rotation of crops (fallow ground or herbage). In certain more difficult type of soils the rotation of the crops was triennial, and beans and herbage, especially tare and oats were cultivated, mainly to feed cattle and a part of it to be turned into hay (Boléo, 1973). Some times, year wheat or barley grew during the first year, followed by fallow ground every other year (Pinho, 1916). Maize was frequently cultivated in vegetable gardens rotating with beans and potatoes, which were cultivated quite frequently alongside with other vegetables. We must also refer to vineyards that occupied many parcels of land, especially on the terraces down to Cheleiros stream (Baleia, 2009).

Concerning cattle raising, it's worth a reference to bovine, ovine and swine raising. As far as bovine cattle is considered, the animals used to labour on the fields were the mirandesa breed and the dairy cattle was in general aturinadas cows, which is a mixed breed with Dutch stock (Pinho, 1916). With regards to sheep, the most abundant cattle in the region, its prevalent stock was caréu or charnequeiro, which is a mixed breed of merino and pirinaico. One of the last inhabitants of Broas, Mr. João Baleia, had once in the past almost a hundred heads of cattle (Baleia, 2009). These flocks of sheep, that could also include goats, used brushwood spots as pasture land in the area, as well as harvest fields, fallow ground and meadows in marshlands. With regards to swine raising, most of the animals were of the bisaro breed (Pinho, 1916) and many farmers had usually one or two in the traditional "megalithic" pigsties.

\subsubsection{The traditional architecture}

The saloia house is also in itself a complex subject, which is the cause of some passionate arguing among some authors. However, we don't want to debate this question here, but to present the architectonic characteristics that allow us to define what it is the saloia architecture. The main aspects to be considered are: the importance of the Moorish inheritance and its crossing with the Christian, the filial relation in the south Mediterranean model of the house, the rural character and its vernacular sense where the erudite intromissions are very subtle (Fernandes \& Janeiro, 1991). The main typologies of this house are the following: ground floor type, with covering of two or four slopes; tower-shaped type with four slopes covering and two floors body; type of two floors in a row, with four slopes but only one body, and finally the two floor type but with several bodies, in parallel or perpendicular arrangement. The agricultural and animal implements and cellars are contiguous or exactly attached to the main habitation, without however making part of it. (Ribeiro,1961). The great particularity of this architecture is the utilisation of dry-stone walls with a strong plaster-work that prevents the stones from falling down. Concerning the interior, the house entrance, currently called "the room", usually had the jar stands and the buraca (wall hollow). The jar stand also served to display the terrine and plates and some other objects, while the buraca is "a sort of closet without door (...) white cloth curtains (...). It occults pictures, memories of the family..." (CMS, 1956). To the side of the entrance house exists the kitchen, with the oven. The oven is one of the main characteristics of the saloia house, because its volume is easily identified in the architecture (Caldas, 1999). It had the double function to cook food and to provide heating to the house. When the house had two floors, it had a stack of stairs in the entrance house that led 
to the rooms that were on the first floor, generally two: one for the young boys, and another one for the parents and the young girls (CMS, 1956).

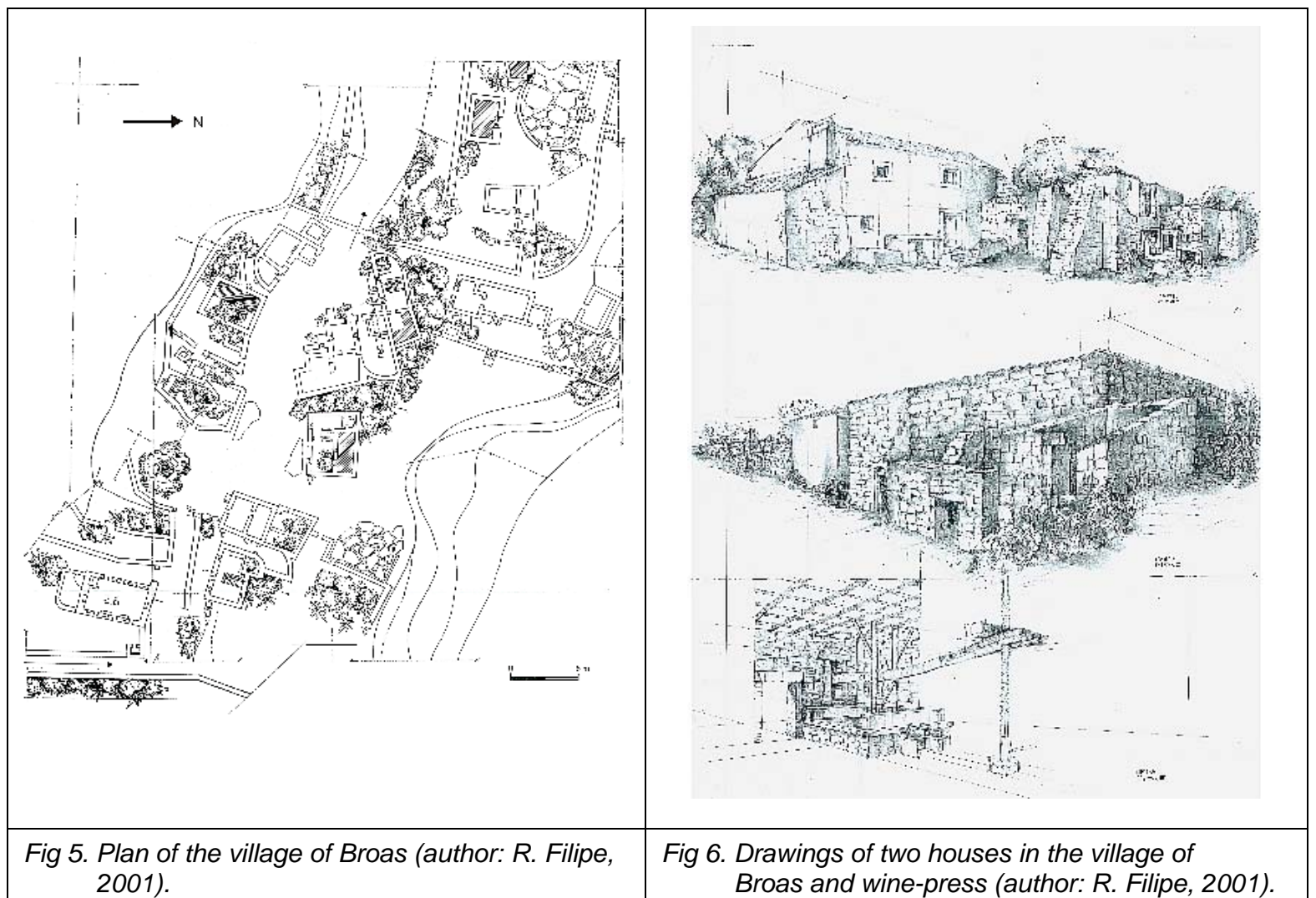

The maintenance and conservation of this vernacular heritage, considered "minor" during long time, is absolutely necessary as it allows the recollection of the forms of life and drudgery of generations who preceded us, and therefore the preservation of their memory (Châtelain, 1998). This matter receives an increasing public interest, and is the subject of reflection on the part of experts of heritage and land planning (Chiva, 1994; Asquith \& Vellinga, 2006).

- Description of the village

The village built heritage was surveyed twice: the first time in 2001, and the second time in 2009. In eight years, the village suffered a fast and strong degradation, so the data collected in 2001 were essential and so was the present testimony of Mr. João Baleia, resident in Broas, in the fifties.

The village is composed of 14 buildings, six of which were for habitation purposes, being the remaining buildings agricultural houses (Figure 5 and 8).

In these six habitations, the recurrent typology is of the cubical house with two floors in a row, some of which have the oven attached to the house (Figure 6). The roof was, in the majority of the cases, with four slopes (Figure 7). All houses had standing out chimneys. Inside, the buraca and the jar stand are still perfectly visible, and so are the oven and the stone benches in the kitchen. In 2001, in some of the houses, the salting-boxes still existed. Now only one subsists. Outside each house there was a pigsty (Figure 9). There were also benches, commonly called namoradeiras (flirtation benches).

The village of Broas was never inserted in a communitarian economy, although communitarian public spaces existed (Figure 7). Two threshing-floors inside the village were used by all the community and there was a private one with twelve meters diameter. The wells were also communitarian. One of them, with 2.20 meters of diameter and 3.5 meters of water depth, is a very interesting vernacular heritage structure. But the communitarian characteristics finish here since the remaining wine-presses were private, as well as the land culture. The wheat was led to the region's mills, and the remnant part, after the miller payment, was for internal consumption and the existing excess was flowed off in fairs. The local economy was possibly made by exchanges between the communities, but this question deserves to be clarified. 


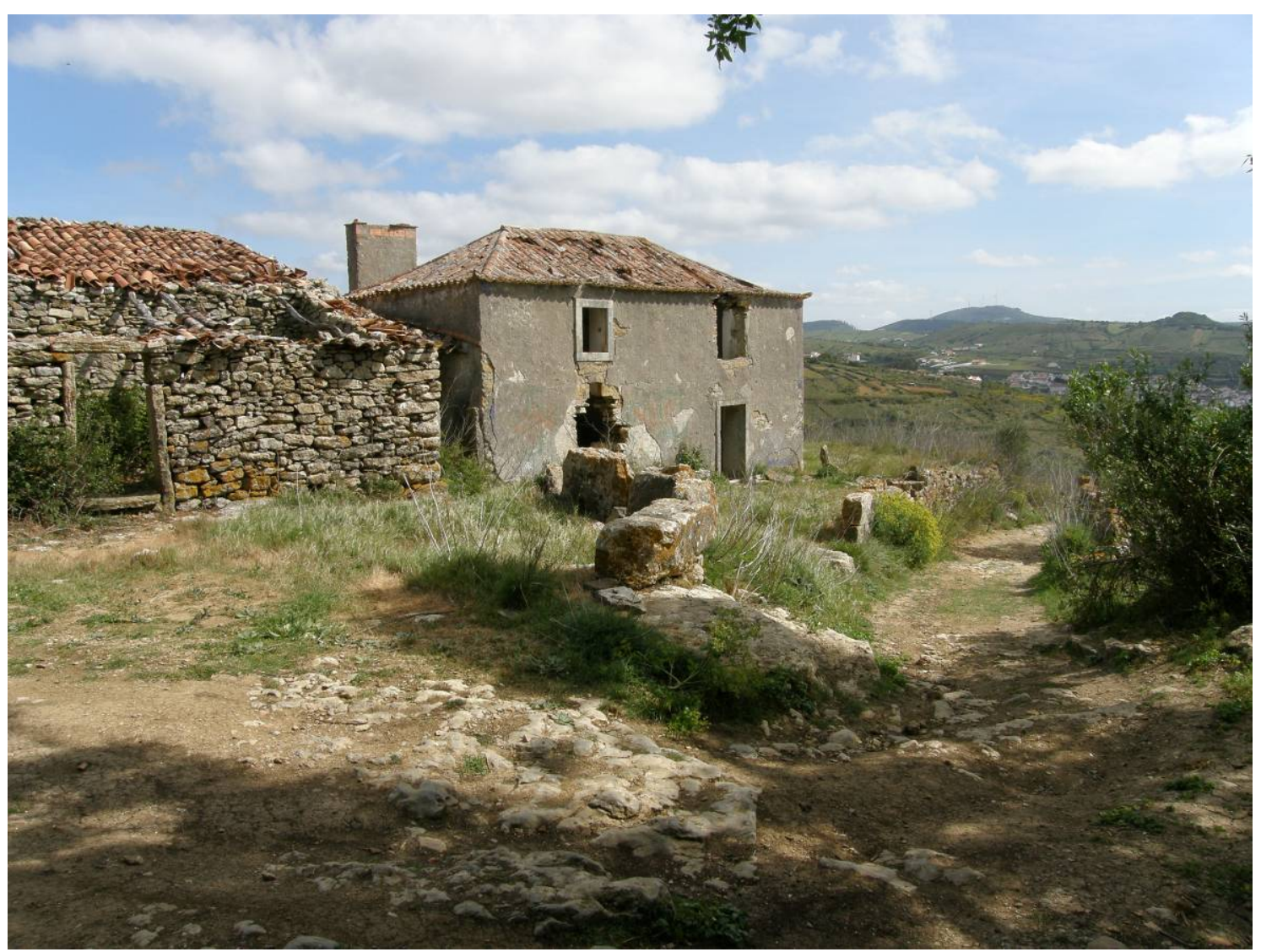

Fig 7. View of two houses in the village of Broas (belonging to Mr. Baleia) and public yard (author: J.M. Mascarenhas, 2009).

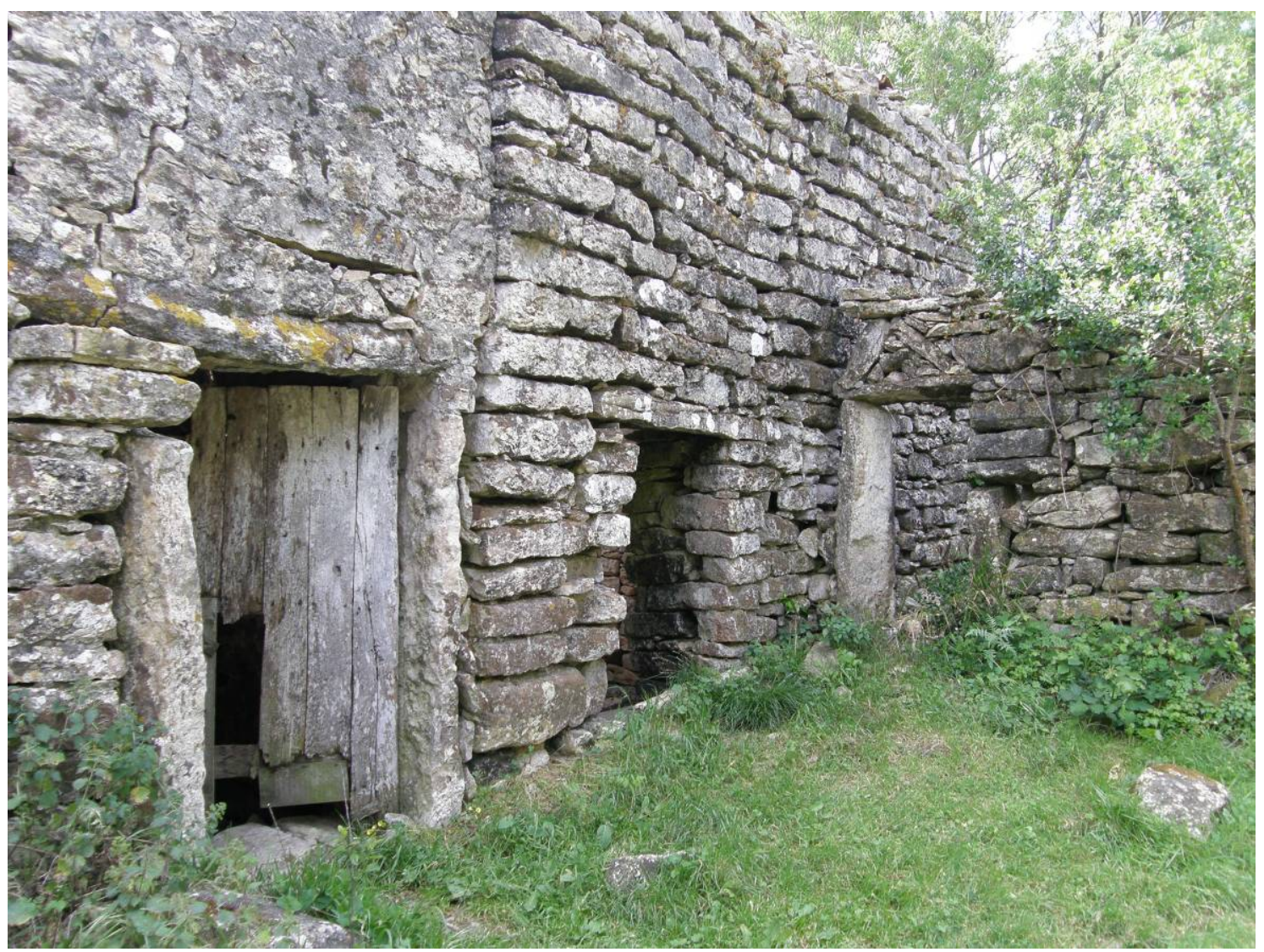

Fig 8. View of architectonic elements of a cottage in the village of Broas (author: J.M. Mascarenhas, 2009). 
As for the community's way of life, in what respects the cultural, educational and judicial aspects, the information is not very rich and its transmission is mostly verbal. The information collected allows us to conclude that in 1950 about 25 people (6 to 7 families) lived in this village. The children attended the school of Cheleiros and any legal official matter was solved in this locality. The meetings of the village were held under the secular ash-tree, that served as a meeting and social point of the community. When balls were organized, they took place in private houses, mainly to the sound of the harmonica. Children were born inside the house, with the help of neighbours. When a death occurred, the deceased was mourned in the house and then carried to the Cheleiros cemetery.

Finally, it must be referred that the population of this village was probably very united, because of the isolation of the village. The old residents keep in touch nowadays, although some of them abandoned the village over 50 years ago.

\subsubsection{Other Heritage Values}

\subsubsection{Natural heritage}

- Vegetation heritage

In what concerns the vegetation heritage of the involving area of Broas, the forest spot installed in old agricultural parcels of the declivous hillside of the Cheleiros stream valley should be emphasised (Figure 2). This hillside correspond mostly to limy lands of the Cretaceous where forests, mainly of Portuguese Oak (Faginea Quercus subsp. broteroi) pertaining to the series Arisaro-Querco broteroi sigmetum, can be observed. Some species of heritage interest, mostly endemic and of communitarian interest, should appear here, having in account the affinity of the pedo-climatic conditions with the ones of a neighbouring area (Farm of the Serrões), studied by Ana Rita Neto, in which were identified (Neto, 2008):

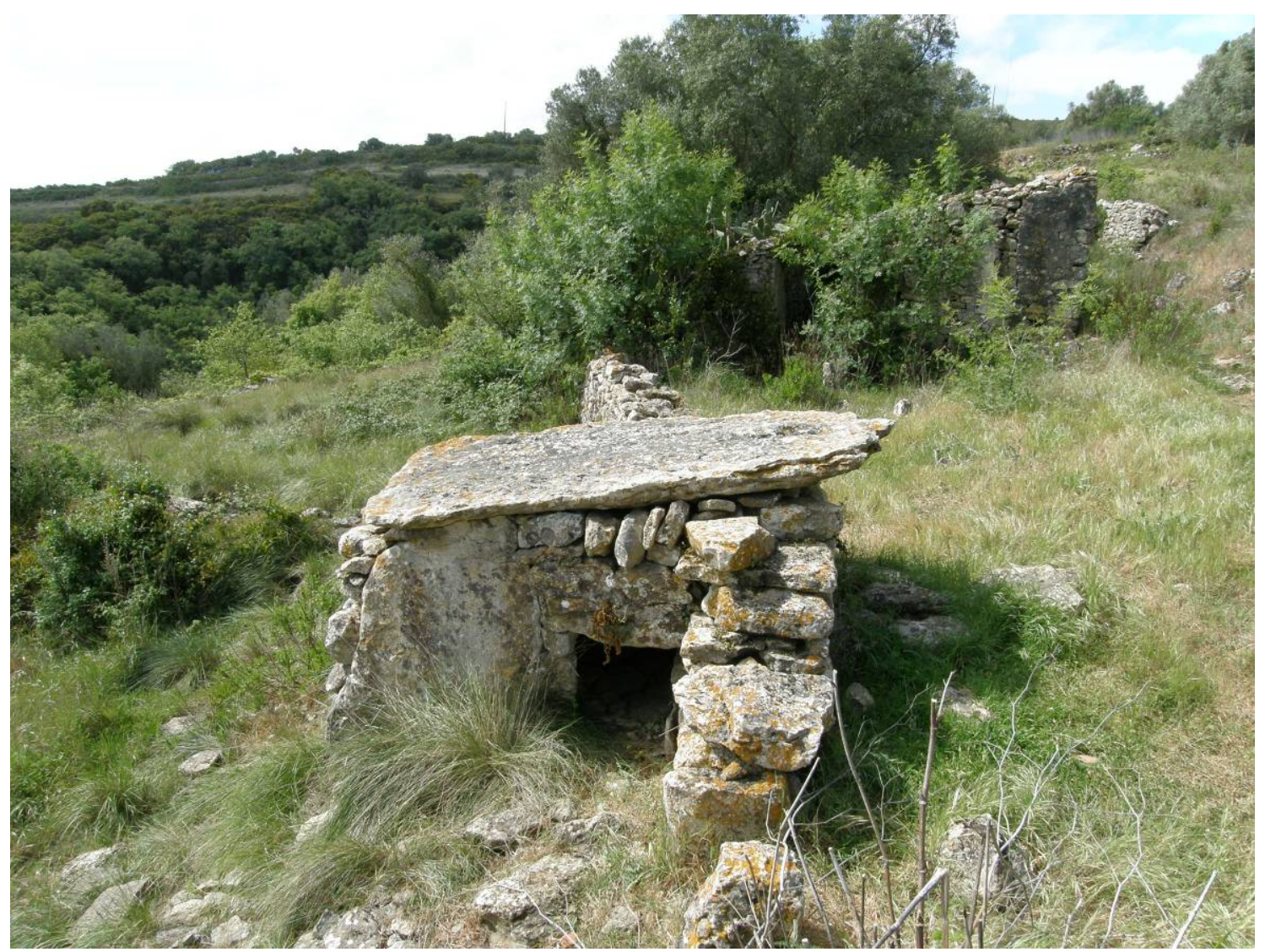

Fig 9. View of a "megalithic" pigsty in the village of Broas (author: J.M. Mascarenhas, 2009).

1) Species of communitarian interest (Attach $\vee$ of the Directive $92 / 43 / \mathrm{CEE}$ ):

- Narcissus bulbocodium L. (common name: petticoat daffodil); 
- Ruscus aculeatus L. (common name: Butcher's broom);

2) Species of communitarian interest (Attach II of the Directive 92/43/CEE):

- Ionopsidium acaule (DC.) (common name: violet cress; lusitanian endemicity);

3) Other lusitanian endemicities:

- Prunus spinosa subsp. insititioidis (Fic.\&Coutinho) Franco (common name: blackthorn subsp.);

- Ulex airensis Espirito Santo (common name: gorse).

Finally, a tree that has a symbolic interest and a great heritage value: it is the ash-tree (Fraxinus angustifolius Vahl) which stands in the main square of Broas and around which the elders sat.

- Faunistic heritage

It can be considered that the Broas involving area presents, in general terms, an upper middle richness in biological fauna, based on the following data:

- Bird fauna (Equipa Atlas, 2008) - Of the native species with a confirmed regular nest building, with regards to:

a) Passeriform Order, 14 species are known in the Berna Convention, 5 in the Bona Convention and 3 on the Bird and Habitat Directives;

b) Anseriform Order, 1 species is known in the Berna Convention and on the Bird and Habitat Directives;

c) Falconiform Order, 1 species is known in the Berna and Bona Convention.

- Mammalogical fauna (Matias, 1999), with regards to:

a) Order of the Insectívora, 6 species are known in the Berna Convention;

b) Order of the Chiroptera, 11 species are known in the Berna Convention and on the Habitats Directive, 7 of them are in danger, according to the Red Book;

c) Order of the Rodentia, 1 species is known in the Berna Convention and on the Habitats Directive, considered "rare" in the Red Book; another species is known in the Berna Convention;

d) the Order of the Carnivore, 3 species are known in the Berna Convention and on the Habitats Directive, and 3 others in the Berna Convention.

- Amphibians and Reptiles (Loureiro et al. 2008):

a) Amphibians: 8 species are known in the Berna Convention, and 3 of these are in the Habitats Directive, one of them being "in danger", according to the Red Book;

b) Reptiles: 18 species are known in the Berna Convention and 5 of these in the Habitats Directive being, in accordance with the Red Book, one "almost-threatened" and two "vulnerable ones".

To the UTM grid unit $(10 \times 10 \mathrm{~km})$ where Broas is included, corresponds a specific richness class (number of species) "average-high", that is, for a total of 11 classes, the unit is placed in the ninth position (idem, 2008, p.80).

\subsubsection{Landscape heritage}

A cultural landscape does not only result from a natural space, but also from its transformation in function of social, economical and cultural concerns, and should be considered "as a cultural construct in which our sense of place and memories inhere" (Taylor, 2008).

Some of these landscapes have a great patrimonial interest, a reason why they can be designated Heritage Landscapes.

The heritage landscape must be faced as a hybrid heritage because it results from a dynamic process of co-production of a new recomposed object (Marchand, 2007). The forms of the Past 
are permanently re-actualized and enriched, they give origin to emergent forms resulting from the self-organization dynamics (idem, 2007).

The landscape proceeds from an intermesh not only spatial and temporal, but also social and physical. One aspect explaining such intermesh is the Law of the Persistence of Plans, which is applicable to urban structures as well as to the agricultural parcels network. According to it, there is the following tendency: the ground patches limits are supported by remaining limits of parcel nets of previous times.

Bearing in mind that the Broas area was greatly occupied in Roman times (Rodil \& Carvalho, 1995), it is very probable that limits of the actual land parcel net coincide with part of a possible Roman net. As the cultural landscape frequently retains information lost by History, a deepened study in landscape archaeology, particularly about the cadastral structure, would be able to reach safe conclusions.

\subsection{Analysis of Broas abandonment causes}

As mentioned in 4.1.2, the village of Broas was integrated in three different municipalities (Sintra, Cheleiros and Mafra) along history.

Its geographic position on the boundary between Sintra and Mafra (Figure 4) could explain the lack of interest in this village from both towns. It never received any municipal intervention to give the village the minimum conditions of access and habitability (roads, water supplies and light). This will have decisively contributed for the total exodus of the resident population.

Even though the causes of the abandonment of Broas fit in the general context (search for better life conditions), the regional socio-economical frame is very different from the one of the depressed inland agricultural areas. As a matter of fact, there is an intense land search for new constructions accompanied by a regular increase of the land price. Besides, some agricultural parcels involving Broas continue to be cultivated by farmers living in neighbouring villages.

\subsection{Some approaches to Broas heritage valorization}

Not as most of the abandoned villages, Broas is within a triangle of great tourism interest (which vertices are Lisbon, Sintra and Mafra), being also very near to the Sea and to a vast natural and cultural patrimony and to sceneries of surpassing beauty. Sintra was elected an area of «World Heritage» by UNESCO. Both Lisbon and Mafra have also made applications for the World Heritage: Mafra with its magnificent Palace/Convent and Lisbon with the immaterial Fado Heritage (traditional Portuguese song). This region is of great tourism interest, attracting the most different publics.

What strategies may be followed for valorizing the site bearing in mind the specificness of this case?

Although there is not yet the purpose to directly intervene in Broas and its involving area, some ideas for its valorization and recovering can be presented, enhancing the pros and cons of each proposal.

\subsubsection{The integral tourist enterprise approach}

The full, or almost full, reutilization of the traditional habitat corresponds to a desire of conserving the built space through a new type of functional use. In practice, this has often been difficult because of the complexity to articulate heritage safeguarding and tourist valorization (Dubost, 1990). Póvoa Dão (Beira Alta), S. Gregorio (Alentejo) and Pedralva (Algarve) are three Portuguese villages integrally dedicated to tourism. All have in common the fact of not being totally abandoned at the date of its recovery. This means that the local population could help to collect essential information, as references about ownership. This question is relevant since properties often belong to several heirs, whose identity and address are unknown, which makes any transaction impracticable. In the villages mentioned above, the component of rehabilitation was well succeeded as the current owners and promoters of these tourist units were concerned with a rehabilitation integrated in the landscape and used processes, techniques and adjusted 
construction materials which did not wound the vernacular local architecture. In all these places, a "happy heritagizing" (Pereiro Pérez, 2003) took place, that is, there was an attempt to recreate a pleasant environment with positive aspects. Actually, the visitor, and of course the tourist, does not want to come across less pleasant social, aesthetic and political factors, although the type of tourist who looks for this market fits into a very specific parameter, he belongs to the urban middle class, with interest in environmental issues and traditional values. The attractiveness of these "tourist converted" villages could be improved through the installation of interpretation centres or thematic museums (ethnographical, archaeological, environmental, mixed, etc.). Beyond the landscape and cultural values, this tourist looks for interactivity and when he makes contact with the local population, for example, through his participation in traditional agricultural activities, it contributes to revitalize the local agricultural economy and to keep the activity of small farmers. This is very important to maintain the involving cultural landscape of the village. Two other questions appear in the context of this problem: the food economical basis of the tourist village risks relying on centres outside the area, which would not benefit the local economical activities, and on the other hand the pronounced inter-seasonal demographic fluctuation, which would create administrative and management difficulties to the enterprise. One should point out that this integral tourism solution cannot be applied universally since an excess of offers quickly would make it unviable in a sustainable development context.

\subsubsection{The museological approach}

Following the above mentioned description of Broas, it becomes essential to safeguard this saloia village as well as the nature and landscape environment involving it. The museum creation seems one of the more evident solutions. But what type of museum and how to prevent the excessive flow of tourists? There are no definitive answers, however there are clues which can be followed, such as participation of the population, territory, collective memory, social object, interdisciplinarity, communitarian development, creativity, life quality (Nabais, 1993). Without the active participation of the population, without a cultural and even emotional involvement with the heritage, the risk of losing its intrinsic identity is bigger, leaving only an accumulation of objects and not an experience that must be "experienced". For the village of Broas, we consider two different museological alternatives: an Eco-museum and an Interpretation Centre.

Applying the Eco-museum definition, the museological area should not be limited to the village but to a vaster area. Our proposal is to put Broas as the central axle of a such museum, enhance its saloio character giving central importance to the natural, built and landscape heritage. The agricultural landscape, consisting of a field mosaic and remains of old terraces, contextualizes the relationship of this village and other ones with the environmental frame, as for example the valley of the Cheleiros stream. The village of Cheleiros, for its historical and cultural importance, should be another nucleus of this eco-museum, as well as the mills of Almocrim and Carvalhal. So it would be convenient to extend the area to Carvalhal, Cheleiros and maybe other villages that are not mentioned here but may disclose natural and/or cultural interest. The different nuclei of an eco-museum show more easily the way the agricultural communities interact and, in this case, the specificities of the so called saloia area. It is essential that this eco-museum safeguards the "know how", that is, the traditional arts and crafts. This aspect is of double importance: it allows to recover and to maintain techniques at risk of disappearing and on the other hand it creates direct and indirect jobs and other increased economical values.

To create an Interpretation Centre in the Broas area is another solution to be considered. The interpretation centres are structures with services for interpretation, communication and exploration of the cultural heritage and are meant to satisfy a new social search. Nowadays, one tends to give more importance to the understanding of the heritage rather than just an aesthetic presentation; so an interpretation centre that offers a legible exhibition, contemplates guided visits and is able to build a relationship between the visitor and the visited place will have much more profitable results than a simple contemplation of objects and rituals. In Broas, this would be one of the options: to stabilize the ruins allowing them to be visited without risk and then to establish an interpretation centre. The main subjects could be the saloia 
life, the agricultural life at the beginning of the $20^{\text {th }}$ century, or the history of the village. The exposition of some objects well identified in their context would allow to establish bridges and comparisons between the life in the beginning of $20^{\text {th }}$ century and the present time. Beyond the importance that an interpretation centre has for the cultural heritage, its social and economical function must also be considered as exposed below.

\subsubsection{Other kinds of approach}

Another option to consider for this abandoned village is, eventually, the repopulation of the village by its old inhabitants. This idea was transmitted to us by one of them, Mr. João Baleia, who showed his desire to come back to his old habitation if minimum conditions of housing were installed such as piped water, electricity, sewers and accesses. However, this option raises other questions: with the repopulation of the village, is it possible to maintain its patrimonial character? And what guarantees of keeping these same characteristics?

So that the patrimonial values of the village are not lost, the intervention of the local autarchic power (Mafra municipality) is absolutely necessary with the classification of the village. It is also essential to elucidate the population on the patrimonial value of the village, motivating it for its conservation and preventing, in this way, the resultant architectonic depersonalization of volumetric alterations of the houses, habitat extensions and apposition of decorative elements exogenous to the local traditional architecture, among other very common errors.

Finally, it is also necessary to be known, without any doubt, if the old population of the village wants to reoccupy it or if we are before just an emotional memory. In case this option becomes possible, it is important that the houses that will not be occupied by their old inhabitants be inhabited by new inhabitants, whether they are farmers (commonly called the neo-rurals), craftsmen or people with other activities in the region.

In any way, such a reoccupation will only be sustainable if conditions of subsistence are created, not only in agriculture but in other activities that can be combined with the primordial objective (preservation and valorization of the architectural heritage), as for example, museum activities, environmental or eco-tourist nature activities.

\section{The re-invention of the Rural in an ecological sustainable context}

\subsection{The revival of old villages, multifunctional systems and micro-geo-economy of rural spaces}

A close report should exist between the revival of old villages and the revival of micro-geoeconomy in the involving areas.

The globalization renders more and more critic the conditions of economic activities reproduction, mainly those settled in depressed rural areas, important reason to think economy in the future in multifunctional terms (Covas, 2008).

The micro-geo-economy of low density rural areas deals particularly with natural resources rarefaction, dispersion, and deterioration (biophysics capital) and the disruption of social relations and present or leave out human resources (social capital). In front of irreversible situations concerning those two capitals reproduction, the oriented multifunctional management towards a familiar group agriculture is a security network aiming "to retrieve the lost time" and to bring the referred capitals to less critical development levels. In this context, ecosystems management must prevail over economic systems management in a very difficult compromise (Covas, 2008).

The multiple functions of agriculture include products as well as less tangible elements, such as social inclusion, cultural heritage and landscape value. There is, in general, a consensus that when multifunctionality is applied, should be firmly area-based (Fleskens et al., 2009).

The agro ecosystems functions can be classified as following:

- Functions are defined as ecosystems functions with humans (potentially) attaching to functions (de Groot et al., 2002, cit. by Fleskens et.al., 2009); 
- Functions are defined taking a broader, human-centred perspective including types of capital other than natural capital (Gómez-Sal et al., 2003 cit. by Fleskens et. al., 2009).

Combinations of the above approaches are possible taking a hierarchical approach to ecosystem functions at the basis and other functions as "derived" functions.

Traditional agro-systems, as olive groves in Northern Portugal "Terra Quente", perform important ecological and social functions. They have been expanding and will progressively strengthen economic functions at the regional level counter weighting to ongoing emigration (idem). They are useful to wildfire control and contribute to a minimum service level in rural areas. On the other hand a minimum maintenance standard of terraces should exist since they are important for the erosion control and as a landscape value. The development of tourism is also important in terms of employment generation. "Policy-makers may use function assessment as a tool to design appropriate agri-environmental subsidy schemes and crosscompliance rules that are tailored to regional agro-ecosystems and seek to achieve balanced rural development" (Fleskens et al., 2009).

Concerning the sustainability of rural development, the reports between tourism, environment and agriculture activities should compose a virtuous triangle, where quality of life is the hyphen. For this purpose almost two conditions must be accomplished: first of all tourism must precede the other two in terms of normative action; secondly, public politics must promote, recognize and reward the planning functions and global landscape reconstruction credits (Covas, 2008).

Henceforth the global quality of tourist product is directly reported with landscape global quality which integrates natural and cultural heritage values with rural-urban continuum quality, as well as with food agriculture, public health, history and local literature (idem).

\subsection{The Cultural Park concept: a model of multifunctional activities and tools development}

The application of Cultural Park concept (Barata \& Mascarenhas, 2002; Mascarenhas \& Barata, $2005 a, b)$ to Broas village and involving cultural landscape can be a new interesting way to give value to the region .

Cultural Park is a model of active participation, the applicability of which is related with the conservation and valorization of cultural landscapes and aims at the improvement of rural population quality of life, land's memories preservation, sustainable development new practices, new areas of knowledge and apprenticeship. The Cultural Park contributes also to a holistic approach to the landscape values understanding. In order to answer to the appeal coming from the international organisms, the Cultural Park means to be an instrument of land planning, of environmental promotion and protection, of heritage maintenance and management, as well as a new means of pedagogic formation and action. All initiatives that allow the economic promotion of local populations contribute to restrain the actual rural population decline.

The development of innovative methods for working together and of new critical approaches to a better sustainable valorization and development of rural areas is another goal to be attained.

Finding out and developing new means of land management is a central issue specially in the context of the present rural world paradigm, where farmers need to move towards multifunctional activities and society is demanding both a broad spectrum of products and a high environmental and landscape quality level. In this way (Barata \& Mascarenhas, 2002), the Cultural Parks:

- assume new forms of promotion and environmental protection since the access restrictions and usufruction of the historical and natural estate are only socially accepted if well understood and justified. On the other hand the defence of this estate also depends on an attitude of widened engagement where the State cannot be the only responsible party for the preservation of the heritage and for the definition of the underlying policies.

- are a new form of heritage management

In fact, the cultural parks are based on the supposition that in the management of the patrimonial goods (natural and man-made) one should not sacrifice the logic of 
management of some in relation to others as has been done up to now with the different separate classification categories; it is rather useful to define some instruments of common intervention, which correspond after all to the reality of the terrain. From this point of view, the parks are a new field of experience of managing methods to be developed by the interested institutions, in particular the universities.

- are a new school

The new pedagogic demands, the general scientific requirements and the competition of the new communication and technological means impose that new teaching methods be thought of. In this aspect, the cultural parks, for the variety of instruments they offer, open completely new working possibilities.

At the same time, as the cultural parks are near people this allows human and technical means for new opportunities such as new professional areas and job opportunities in conjunction with tourism and heritage management.

- are in connection with the new economic realities

Throughout the maintenance of traditional agricultural practices and others connected activities, such as apiculture, farmers directly involved in the park project can get evident profits from this kind of actions, mainly in the European Common Agriculture Policy (CAP) frame.

- rely on criteria and on an objective evaluation of heritage

The more general aspects should not forget or lose out of sight the necessity of using for the purpose of valorization of areas which might become cultural parks, objective criteria under pain of badly conceived proliferation of these instruments, diverting them from the objectives which support them. So the definition of the qualitative criteria and, if possible, quantitative, should always be a concern to take into account.

\subsection{But how to improve Broas in terms of tourism in the case of a Cultural Park?}

Over the last years, the environment has taken a place of increasing importance within tourism development. With an appropriate management, Tourism may even be considered as a factor of sustainable development as it has the power to embellish the environment, raise funds for its maintenance and protection and stand up for culture and history (Almeida \& Abranja, 2009).

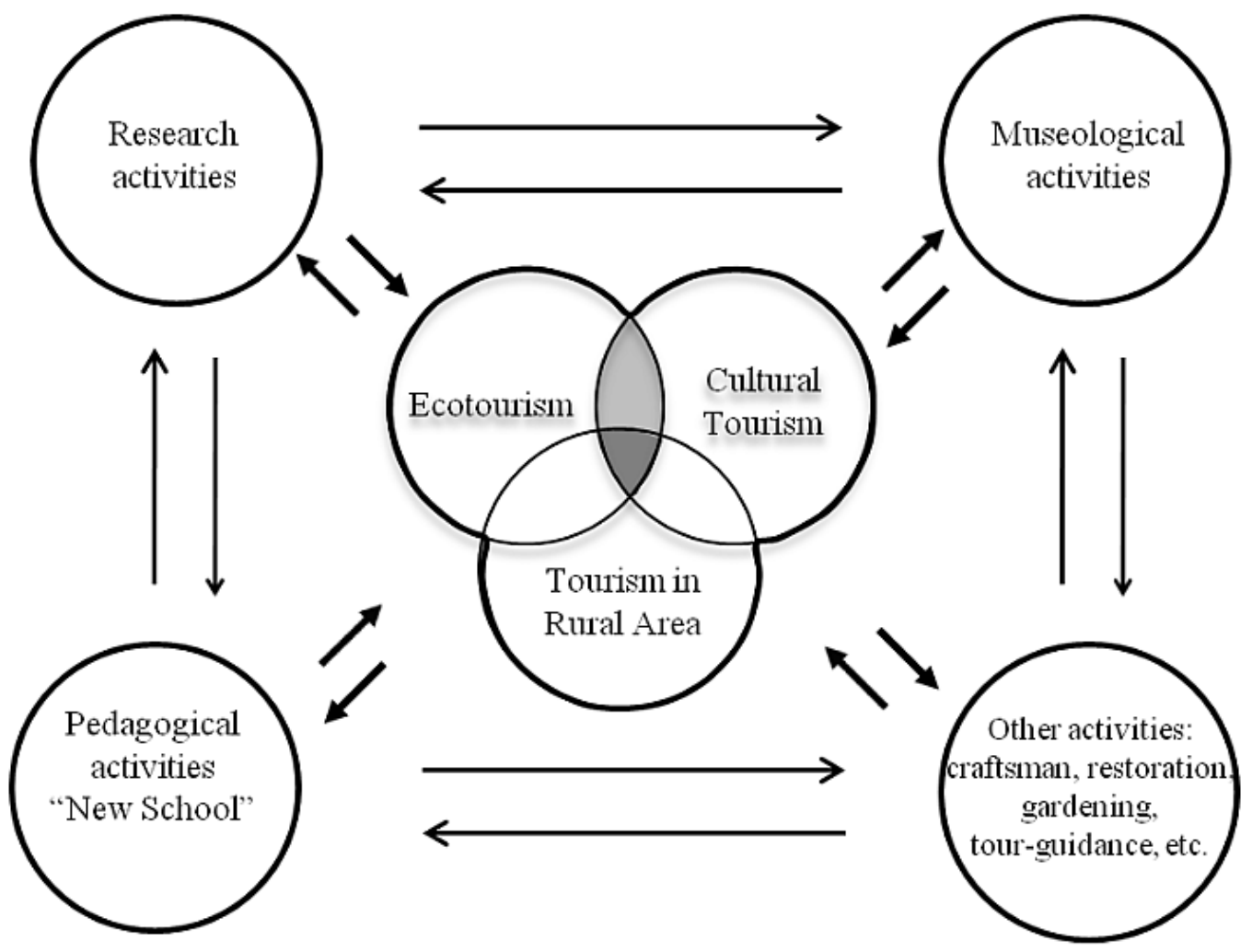

Fig 10. The eco-cultural tourism in a cultural park context (author: J.M. Mascarenhas; drawing: C. Carriço, 2010). 
The type of tourism management to be applied in Broas, will essentially depend on the valorization model to be adopted. The more feasible solution, according to the nature of the structure (an abandoned village), seems to be a moderate valorization making feasible an Interpretation Centre or some more integrated cultural forms, as the case of a Cultural Park. Thus, this development would have as main idea not to explore the village itself, leaving the village clear but only with a partial rehabilitation, mainly in the cases of eminent downfall or other dangers, with rural tourism in the villages of the neighbourhood as one of the main support basis.

These villages will be above all Cheleiros and Murtal, in the municipality of Mafra, and Almocrim, Faião and Odrinhas in the municipality of Sintra, which, in due course, shall have the basic equipments for tourism support, as lodging, restaurants and parking facilities.

The mitigated valorization proposed, mainly with regards to a Cultural Park, is the Eco-cultural Tourism, well-founded by natural sites perceived through its landscapes, flora and fauna, but also through its geography and history, enhancing the "spirit of the place» and the combination of its meanings (Cluzeau 2000).

Such type of tourism, introduced for the first time during the Santander Conference, organised by the European Agency for Culture and by the Fundación Botin, in September 1997 (Cluzeau, 2000), is supported by the principles and methods of ecotourism and cultural tourism (Figure 10). As a concept, it is very similar to what several authors call nowadays "Geotourism» (Buckley, 2003).

The fact that a great part to be considered corresponds to the involving area of Broas, with an important and diverse natural and landscape heritage, turns it into the right place for the development of ecotourism and so for many nature - based activities such as pedestrian visits, horse riding, BTT and other means of non motorised locomotion. On the other hand, the remaining architectural structures, typical of the architecture called saloia, mostly in plastered dry stone walls, are an important vernacular heritage, justifying the development of a specific tourism and cultural programme, which would include visits to structures selected for that purpose, watching of panels and video programs, allowing the visitor to correctly make the interpretation of the referred heritage.

\section{Thinking about operational guidelines and administrative structures}

\subsection{A proposal of operational guidelines}

The presentation of a proposal concerning operational guidelines is reported with the fact that the Broas village and landscape recovery project involves a multidisciplinary approach and the fully integration of the data in policy analysis and design have a certain complexity. For those reasons each abandoned village or area needs a distinctive intervention taking into account its complexity. In Italy where this problem is very serious (about 2500 abandoned villages), Antonio Fabbri, President of Liguria Region Council, presents several practical solutions to be applied in those abandoned or almost abandoned villages in the shape of an operational process (Fabbri, 2006). This report is divided in four thematic chapters: making public opinion sensitive to this problem; establishment of a technical commission; establishment of a Foundation; creation of an operational Consortium. Beyond these solutions, the Condominium creation brain (Covas, 2008) is also presented. It follows then these proposals explanation:

- Making public opinion sensitive to this problem

Making public opinion sensitive to this problem needs adequate divulgence. Positive results can come from this operation: historic and urban heritage values recovery; conservation of craft activity and eventual formation of new artisans following the home-laboratory model; making people sensitive can possibly allow the creation of supports and conditions to small-scale farming or agro-tourist activities; enabling the establishment of educational structures concerning the following areas: urbanism, buildings recovery, history and environment; enabling the creation of "bed and breakfast" type tourist circuits; enabling the settlement of small foreign communities existing in the country but without a stable job in the important urban centres; 
enabling the prevention of abusive occupation and illicit activities; protecting environment in its different aspects; realizing projects to install cable networks and other equipments to allow the tele-work.

\section{- Establishment of a technical commission}

In front of a real case, this commission will outline public administration towards the creation of a model for the abandoned area revitalization, as following: defining, under an administrative point of view, the abandoned village concept and imputing a specific juridical physiognomy; receiving the recovery intervention guidelines reported in the programme minutes related with land, landscape, building and economic planning; enabling the intervention of heritage and landscape entities towards a possible cultural bond declaration of the abandoned village allowing the application of coercive means; enabling the acquisition of property cadastres information permitting to identify and localize landowners; to be willing to collaborate with local associations and universities in a recovery-type project; searching financing sources at a national and European level.

\section{- Creation of a Foundation}

The making-up of a Foundation or of another juridical figure with public and non-lucrative aims that will take possession of the single abandoned real estates and will proceed with the land survey, with the census of the goods and the application of the abbreviate acquisitive prescription (usucaption) to the small rural property, respecting the private property institute.

- Creation of an operational Consortium

In this Consortium will participate the landowners, the referred Foundation, the craft, commercial and tourist Associations and the prerogatives are:

- To search public, national and communitarian financing, as well from bank Foundations or private Societies interested in the sponsorship;

- To prepare preliminary and executive technical projects as well their presentation and approval;

- To attend private landowners;

- To realize building interventions;

- To grant the free use or letting out on lease to individuals through public procedures, in the context of the followed goal.

\subsection{Administrative figures possibilities}

The Condominium (Covas, 2008) is another kind of juridical figure that can be considered. It can be imported without serious risks and can be an association, a cooperative, an enterprise, a university, an autarchy, or in preference, an association of these entities. And as the promotion of the multifunctional familiar agriculture is desirable in the context of a Cultural Park implementation, the feasibility of the agro-rural system will be subject to the possibility of realizing multifunctional land contracts managed by the Condominium directors (idem).

Finally it is interesting to refer that there is no incompatibility between Fabbri and Covas proposals. On the contrary, they can complement one another. A Condominium application for example, should be always preceded by making public opinion sensitive to the problem. In a multidisciplinary EU context, thinking and discussing those proposals together will be a first step to control the problem and protect vernacular heritage. Nevertheless it seems essential that CAP politics advances in the sense of a preferential support to familiar agriculture under an organized and contractual multifunctional form through collective land contracts. In this situation it is perhaps yet possible to regard rurality as a generous aim of culture and civilization (Covas, 2008). 
However, from our point of view, the more adequate jurisdiction for a Cultural Park is an Association or a Consortium (in the sense of Fabbri). The first one is an organisation resulting from the legal association of two or more persons, with or without corporate identity, in order to reach a common purpose.

The owners, the municipalities involved (Sintra and Mafra) and «village friends» should all be included in that organisation. With the perspective of employment generation, commercial activities will probably develop, within the most different branches, whose responsible persons should be part of the Association.

In a first stage, the Association should look for support from the above mentioned municipalities. The project basis may only be launched with logistic and financial support. The Association should also provide the preparation of a technical project, showing the advantages of such a project, as for example the generation of direct employment (3/4 within the area of Broas) and indirect employment, through the development of houses for rural tourism.

This Project is in fact a work document with a thorough study of Broas and neighbour villages, with the essential actions to be adopted to promote the integrated development of the region.

The installation of basic infra-structures, as sewage, water supply and electricity, together with the re-qualification of spaces, public buildings and private ones, are a few of the prior interventions.

With this jurisdiction structure it will also be possible to look for financing in communitarian projects and or national, as is the case of the Leader Project supporting the development of the depressed rural zones and also the vernacular heritage maintenance. But unfortunately the area in which the village of Broas is situated is not part of the areas comprised in these projects, until 2013. Despite of this reverse, it will be possible to obtain a banking loan, through the PME III credit line, which has a low interest rate, as it is a Government incentive for investment and development of economical activities.

However, we would remind that such opportunities are only feasible if the Association is duly established and has as partners Sintra and Mafra Town Councils and have the support and engagement of the owners, without which nothing will be possible.

\section{Conclusion}

After analysing the causes and effects of rural abandonment that is affecting mainly the agriculture marginalised inland zones, Broas village case was particularly studied. Settled in the periphery of Lisbon metropolitan area, this abandoned village should be seen as a special case, as it is inside a developing zone, the land value of which is rising with regularity. The abandonment causes are probably more related with its location on the frontier of two municipalities than with other reasons. Presenting a significant vernacular heritage, the recovery of this village and involving traditional landscape is convenient. As the Cultural Park figure seems the most interesting way for the rehabilitation and valorization of the area, the guidelines for such a creation were exposed as well those concerning a possible operational process. It is important to consider in such process the recovery of productive systems in an agroecosystemic basis and taking into account a high environmental quality. The creation of juridical figures as a Condominium, a Foundation or a cooperative Consortium, involving the municipalities, the farmers or other landowners, the associations and other stakeholders seems interesting to the Cultural Park management. However CAP politics advances in supporting small-scale familiar agriculture is an important issue to slow down rural abandonment and to the conservation of landscape.

\section{Aknowledgements}

We cordially thank to the Instituto Geográfico Português (www.igeo.pt), for the permission to use part of the Air Photograph Nr. 336, from 1946 Mafra Mission; Câmara Municipal de Mafra for the documentation facilities; Rui Pedro Filipe, for the loading of Broas plant and drawings; Ana Rita Neto, for the explanations regarding the vegetation heritage; João Baleia and Rogério Filipe, for the interviews about Broas history; Cristina Carriço for the drawing of Figures 1 and 
10; Tereza da Cunha, Mafalda Brito and Isabel Quaresma de Almeida, for the collaboration in the text translation.

References

[1] de Abreu, O Prior Jerónimo Pereira (1998). Memória Paroquial de Nossa Senhora da Assunção de Cheleiros" (20 de Março de 1758), in: Memórias do Tempo, Obras de José Alfredo da Costa Azevedo V (pp.148-151). Sintra: Câmara Municipal de Sintra.

[2] de Almeida, F. Moitinho, ed. (1991). Carta Geológica de Portugal, Folha 34-A, Lisboa: Serviços Geológicos de Portugal.

[3] de Almeida, I. D. \& Abranja, N. A. (2009). Turismo e Sustentabilidade. Cogitur: journal of tourism studies, 2(2), 15-31.

[4] Asquith, L. \& Vellinga, M., ed. (2006). Vernacular Architecture in the Twenty-First Century, London, New York.: Taylor \& Francis.

[5] Baleia, J. (2009). Oral information, 2009.

[6] Baptista, J.M. (1876). Chorographia Moderna do Reino de Portugal. Lisboa: Typographia da Academia Real das Sciencias.

[7] Barata, F.T. \& Mascarenhas, J.M. (2002). Preserving the land's Memories The Tourega/Valverde Cultural Park. Évora: CEEM-Universidade de Évora.

[8] Boléo, J. (1973). Sintra e o seu termo, Estudo geográfico, Sintra: Câmara Municipal de Sintra.

[9] Borges, Prior Sebastiam Nunes (1998). Memoria da Igreja Matris, e Real Collegiada de Sam Martinho da Villa de Cintra (22 de Abril de 1758). In Memórias do Tempo, Obras de José Alfredo da Costa Azevedo, V (pp.115-156). Sintra: Câmara Municipal de Sintra,.

[10] Bronner, S. J. (2006). Building tradition, Control and authority in vernacular architecture. In Asquith, L. \& Vellinga, M. (eds.), Vernacular Architecture in the Twenty-First Century (pp. 23-45). London , New York: Taylor \& Francis..

[11] Buckley, R. (2003). Environmental Inputs and Outputs in Ecotourism: Geotourism with a Positive Triple Bottom Line? Journal of Ecotourism 2(1), 76-82.

[12] Caldas, J. V. (1999). A Casa Rural dos Arredores de Lisboa no Século XVIII, Porto: Faculdade de Arquitectura da Universidade do Porto.

[13] Cancela d'Abreu, A., Pinto-Correia, T. \& Oliveira, R., (2004). Contributos para a Identificação e Caracterização da Paisagem em Portugal Continental, vol. IV, Lisboa: Direcção Geral do Ordenamento do Território e Desenvolvimento Urbano.

[14] CMS (1956). Exposição Etnográfica Saloia do Concelho de Sintra, Sintra: Câmara Municipal de Sintra, Instituto de Sintra.

[15] Cardoso, L. (1751). "Cheleiros". In Diccionario Geografico ou Noticia Histórica de todas as Cidades, Villas, Lugares e Aldeãs... (p.637). Lisboa: Na Regia Officina Sylviana, e da Academia Real.

[16] Châtelain, A. (1998). Patrimoine Rural, Reflet des terroirs. Paris: Rempart \& Desclée de Brouwer.

[17] Chiva, I. (1994). Une Politique pou le Patrimoine Culturel Rural, Paris: Ministère de la Culture et de la Francophonie. (Rapport interne).

[18] du Cluzeau, C. Origet (2000). Le tourisme culturel, 2nd ed. Paris: Presses Universitaires de France.

[19] Coelho, C. (2000). "A ocupação islâmica do Castelo dos Mouros (Sintra): interpretação comparada“, Revista Portuguesa de Arqueologia, 3 (1), 207-225. 
[20] Costa, A. (1936). Diccionario Chorographico de Portugal Continental e Insular, Azurara: Typographia Privativa do Diccionario Chorographico.

[21] Costa, J.C., Aguiar, C., Capelo, J.C., Lousã, M. \& Neto, C. (1998). Biogeografia de Portugal Continental. Quercetea, vol. 0 (pp. 5-56). Lisboa: Asociação Lusitana de Fitossociologia.

[22] Costa, P. F.196). Em Busca de uma Identidade: os Saloios. In Actas das II Jornadas sobre Cultura Saloia (pp. 91-106.). Loures: Câmara Municipal de Loures,

[23] Covas, A. (2008). Ruralidades III, Temas e problemas da ruralidade pós-agrícola e pósconvencional Faro: Universidade do Algarve.

[24] Dubost, F. (1990). Protection de l'architecture rurale dans une région, Etudes Rurales, 117, pp.127-135.

[25] Equipa Atlas (2008). Atlas das Aves Nidificantes em Portugal (1999-2005). ICNA, Sociedade Portuguesa para o Estudo das Aves, Parque Natural da Madeira e Secretaria Regional do Ambiente e do Mar, Lisboa: Arsénio e Alvim.

[26] Fabbri, A. (2006). Una proposta di Consedil per il recupero dei paesi abbandonati della Liguria. Intervento del Presidente Geom. Antonio Fabbri. Retrieved October 12, 2006 from http://www1.zenazone.it/index.php?app=zenazone\&mod=appointments_details\&zone_id=45 \&appointment_id=3039\&\&zenazonelD=8

[27] Fernandes, J. M. \& Janeiro, M. L. (1991). Arquitectura Vernácula da Região Saloia. Lisboa: Instituto de Cultura e Língua Portuguesa.

[28] Fleskens, L., Duarte, F. \& Eicher, I. (2009). A conceptual framework for the assessment of multiple functions of agro-ecosystems: A case study of Trás-os-Montes olive groves. Journal of Rural Studies, 25(1), 141-155. Doi:10.1016/j.jurstud.2008.08.003.

[29] Fontes, Joaquim (1943). Mem Martins, notas Históricas e Etnográficas. Boletim da Província da Estremadura (293 - 299 and 311).

[30] Garcia-Ruiz, J.M., Ruiz-Flano, P., Lasanta, T., Monserrat, G., Martínez-Rica, J.P. \& Pardini, G. (1991). Erosion in abandoned fields, what is the problem?. Soil Erosion Studies in Spain, 3 (pp. 97-108).

[31] González Bernáldez, F. (1991). Ecological consequences of the abandonment of traditional land use systems in central Spain. Options Méditerranéennes, 15, pp. 23-29.

[32] Labille, F. (2007). La Valorisation du Patrimoine Vernaculaire: Une des Actions de prefiguration du Projet de P.N.R. des Pyrénées Ariègeoises, Lyon: Université Lumière-Lyon 2. (Rapport de stage professionnel).

[33] Lopes, I. (2006). As Casas das Câmaras dos Extintos Concelhos da Azueira, Carvoeira, Cheleiros, Enxara dos Cavaleiros e Gradil (seculo XVII a 1855). In Boletim Cultural (pp.175232), Mafra.

[34] Loureiro, A., de Almeida, N. F., Carretero, M. \& Paulo, O., eds. (2008). Atlas dos Anfíbios e Répteis de Portugal, Lisboa: ICNB.

[35] MacDonald, D., Crabtree, J.R., Wiesinger, G., Dax, T., Stamou, N., Fleury, P., Gutirrez Lazpitta, J. \& Gibon, A. (2000). Agricultural abandonment in mountain areas of Europe: Environmental consequences and policy response", Journal of Environmental Management, 59(1), 47-69. Doi:10.1006/jema.1999.0335.

[36] Marchand, C. 2007). Que faire de l'héritage. In Les Actes du Premier Colloque d'Archéogéographie, Paris.

[37] http://www.archeogeographie.org/index.php?rub=bibli/colloques/pre-actes/marchand. Retrieved June 23, 2009

[38] Martínez Martínez, A. (1993). Los pueblos marginales y abandonados. Posibles actuaciones. Agricultura. Revista agropecuária, 729, 333-335. 
[39] Mascarenhas, J. M. \& Barata, F. T. $\left(2005^{a}\right)$. Towards new forms of sustainable land management and valorisation: Cultural Parks. Proc. of the $1^{\text {st }}$ European Networks Conference on Sustainability in Practice (pp.199-206). Berlin: Ed. Kolleg. für Management und Gestaltung nachhaltiger Entwicklung $\mathrm{GmbH}$.

[40] Mascarenhas, J.M. \& Barata, F.T. (2005b). The Cultural Park as a Platform Connecting Human Ecology with Cultural Landscape. Journal of Mediterranean Ecology, 6(1), 11-18.

[41] Matias, M. L., ed. (1999). Guia dos mamíferos terrestres de Portugal continental, Açores e Madeira, Lisboa: Instituto de Conservação da Natureza.

[42] Matta, A. (1981). Evolução histórico-demográfica da região de Sintra. Jornal de Sintra, 20 de Novembro de 1981, p.3.

[43] Mendes, J., Queiroz, D., Anastácio, P., Gonçalves, M., Cardoso, M. \& Coelho, M. (1991). O Clima de Portugal, Normais Climatológicas da Região de "Ribatejo e Oeste" correspondentes a 1951-1980, Fasc.XLIX, vol.II, Lisboa: Instituto Nacional de Meteorologia e Geofísica.

[44] Nabais, A. M. (1993). Nova Museologia - novas práticas museológicas. Vértice 54, II série (pp. 46-48). Lisboa..

[45] Neto, A. R. (2008). Os habitats naturais e semi-naturais da Granja dos Serrões. Medidas de Gestão e Conservação, Évora: Universidade de Évora. Relatório interno.

[46] Pereiro Pérez, X. (2003). Patrimonialização e transformação das Identidades Culturais. In Portela, J. \& Caldas, J. (eds.), Portugal Chão (pp.231-247). Oeiras: Celta.

[47] Pimentel, A. (1908). A Extremadura Portugueza. Lisboa: Empresa da Historia de Portugal.

[48] Pinho, R. (1916). O Concelho de Sintra. Esboço Económico Agrícola, Lisboa: Instituto Superior de Agronomia.

[49] Ribeiro, O. (1961). Geografia e Civilização. Lisboa: Instituto de Alta Cultura.

[50] Rivas-Martínez, S. (2005). Avances en Geobotánica. Madrid: Instituto de España, Real Academia Nacional de Farmácia.

[51] Roca, Z. \& Oliveira, J.A. (2005). A Paisagem como Elemento de Identidade e Recurso para o Desenvolvimento. Paper presented in X Colóquio Ibérico de Geografia (Évora, 22-24 Set. 2005).

[52] Roca, Z. (2009). Paisagem, Identidade Territorial, Desenvolvimento e Terrafilia. Paper presented in the "Sessão de Debate e Reflexão sobre Política Nacional de Arquitectura e Paisagem", Palácio de Monserrate, Sintra, 11 de Março de 2009.

[53] Rodil, J. \& Carvalho, S.L. - (1995). Sintra: as pedras e o tempo: roteiro histórico de Sintra (1959), Lisboa: Grupo de Trabalho do Ministério da Educação para as Comemorações dos Descobrimentos Portugueses.

[54] Sedimayr, A. (2008). Agricultural marginalisation in Portugal: Resistance or Resignation?, Actas do III Congresso de Estudos Rurais (Faro, Univ. Algarve, 1-3 Nov. 2007), SPER/ UAlg, CD-ROM.

[55] Sousa, A. C. (1998). O Neolítico Final e o Calcolítico na área da Ribeira de Cheleiros, Lisboa: Instituto Português de Arqueologia.

[56] Taylor, K. (2008). Landscape and Memory: cultural landscapes, intangible values and some thoughts on Asia. In $16^{\text {th }}$ ICOMOS General Assembly and International Symposium: 'Finding the spirit of place - between the tangible and the intangible', 29 Sept - 4 Oct 2008, Quebec, Canada.

[57] Theil, S. (2009). Para onde é que foi toda a gente? http://www, seleccoes.pt/Common/imprimir.asp?artigo=R_5135. Retrieved 29 ${ }^{\text {th }}$ March, 2009. 